\title{
Nuclear DNA content as an indicator of inflorescence colour stability of in vitro propagated solid and chimera mutants of chrysanthemum
}

\author{
Natalia Miler $^{1}$ D $\cdot$ Dariusz Kulus $^{1}$ (D) Elwira Sliwinska ${ }^{2}$ (D)
}

Received: 22 July 2020 / Accepted: 9 September 2020 / Published online: 15 September 2020

(c) The Author(s) 2020

\begin{abstract}
In chrysanthemum, breeders seek for desirable characteristics of the inflorescence, which can first be established once the plant is mature. The present study aims to determine whether measurement of DNA content can be useful in the detection of somaclonal variants and/or separation of chimera components in chrysanthemum at the early in vitro multiplication stage. Eleven Chrysanthemum $\times$ morifolium (Ramat.) Hemsl. cultivars of the Lady group (a mother cultivar and ten of its radiomutants obtained by X-ray- or $\gamma$-irradiation; solid and periclinal chimeras) were propagated in vitro. Single-node explants were cultured in Murashige and Skoog (MS) medium, either without plant growth regulators (PGRs) or supplemented with 6-benzyladenine (BA) and indole-3-acetic acid (IAA). The nuclear DNA content was measured by flow cytometry (FCM) in the shoots produced in vitro. After acclimatization and growth of the plants in a glasshouse, inflorescence colour was recorded. The addition of PGRs to the medium almost doubled the mean number of shoots produced in vitro per explant, but caused a change in inflorescence colour of all ('Lady Apricot'; periclinal chimera) or part of the plants ('Lady Amber'; solid mutant and 'Lady Salmon'; periclinal chimera). All radiomutants contained less DNA than the mother cultivar 'Richmond'. There were significant differences in DNA content between plants of the same cultivar grown in media with or without PGRs for 'Lady Apricot' and 'Lady Salmon', but no phenotype alternation occurred in chrysanthemums produced in PGR-free medium compared to the original cultivars. Conversely, in medium with PGRs, chimeras produced flowers different from the original colour. In all except one cultivar ('Lady Amber'; solid mutant) a lack of differences in genome size between plants grown in either medium coincided with a stable inflorescence colour. The occurrence of some plants of 'Lady Amber' with different inflorescence colour may be due to small DNA changes, undetectable by FCM. It can be concluded that FCM analysis of DNA content in young plantlets can be indicative of the stability of inflorescence colour in chrysanthemum, especially chimeric cultivars, and for mutant detection.
\end{abstract}

\section{Key message}

Flow cytometry measurement of nuclear DNA content can be recommended for detection of variation in inflorescence colour of chrysanthemums during early in vitro multiplication, especially in periclinal chimeras.

Communicated by M. I. Beruto.

Electronic supplementary material The online version of this article (https://doi.org/10.1007/s11240-020-01929-9) contains supplementary material, which is available to authorized users.

Dariusz Kulus

dkulus@gmail.com

1 Laboratory of Ornamental Plants and Vegetable Crops, Faculty of Agriculture and Biotechnology, UTP University of Science and Technology, Bydgoszcz, Poland

2 Laboratory of Molecular Biology and Cytometry, Faculty of Agriculture and Biotechnology, UTP University of Science and Technology, Bydgoszcz, Poland 
Keywords Breeding · Flow cytometry $\cdot$ Genetic variation $\cdot$ Genome size stability $\cdot$ Inflorescence colour . Micropropagation $\cdot$ Plant growth regulators

\section{Introduction}

Micropropagation is a powerful tool in the large-scale production of ornamental species, including chrysanthemum (Teixeira da Silva and Kulus 2014). It has several advantages over the traditional methods of reproduction, such as the high quality of the resultant plant material, more profitable production, and independence of the season (Kulus 2015). Because micropropagation is a clonal method of reproduction, the plant material that is produced is of high uniformity. However, due to the use of plant growth regulators (PGRs) and regeneration of plants via unstable callus, a genetic and, consequently, phenotypic variation in the in-vitro-derived plants have been reported (Miler and Zalewska 2014).

Methods commonly used in chrysanthemum micropropagation are often based on culturing leaf, nodal or flower explants in auxin- and cytokinin-supplemented media (Teixeira da Silva et al. 2015). Shoot/nodal culture on a PGR-free medium, is generally considered a reliable method for producing genetically identical plants without the occurrence of somaclonal variation. Other pathways for in vitro propagating of chrysanthemum with little risk of the occurrence of somaclonal variation are direct shoot organogenesis and direct somatic embryogenesis. However, PGRs supplementation, which is mandatory with these methods, can cause significant variation and changes in the genotype and often phenotype of regenerants if a callus phase occurs, i.e. in the indirect organogenesis and indirect somatic embryogenesis methods (Teixeira da Silva et al. 2015). Miler and Zalewska (2014), obtained new genotypes of Chrysanthemum $\times$ grandiflorum (syn. C. $\times$ morifolium) that were considerably different in inflorescence colour from the mother cultivars, using callus induced from leaves and internodes cultured in the medium supplemented with 6-benzyladenine (BA) and indole-3-acetic acid (IAA). For example, among plants obtained from 'Alchimist Tubular', in addition to those with silver violet inflorescences typical for this cultivar, there were three with golden brown inflorescences and one that was golden red. This colour change was explained by the presence of carotenoids, which were absent from the mother plant inflorescences (Miler and Zalewska 2014). Because of the occurrence of such variations, it is important to reliably assess the stability of newly produced plant material before rooting, acclimatization, and cultivation in the glasshouse, to exclude or select altered individuals, depending on production/breeding goals.

There are two main causes of variation in micropropagated chrysanthemum plants: somaclonal variation, which occurs de novo as a result of specific in vitro conditions
(Larkin and Scowcroft 1981), and the separation of chimera components, which is an expression of existing variation between histogen layers (Miler and Zalewska 2014). Variation induced or revealed during micropropagation is undesirable in the commercial production of ornamental plants, and as a consequence of failing to deliver true-totype plants, producers are exposed to considerable loss of income and customer confidence (Kulus et al. 2019). On the other hand, somaclonal variation may be used as a source of variation facilitating relatively easy, cheap, and fast production of new phenotypes (Miler and Jędrzejczyk 2018). The effect of in vitro culture, especially medium composition and explant type, on plant DNA content can be on the whole genome (polyploidization), or of smaller, chromosomal and single genes extent, all possibly leading to alternation of trait expression (Neelakandan and Wang 2012).

Phenotypic stability is a particular consideration during commercial production because many modern cultivars of ornamentals are periclinal chimeras, i.e. plants with an entirely changed single histogen layer, which cannot be visually distinguished from that of a non-chimeric plant and requires more advanced, molecular methods of identification (Zalewska et al. 2007; Kulus et al. 2018). Chimeras are susceptible to the rearrangement of histogen layers with different genotypes, and, as a consequence, their separation in progeny plants, which manifests as the change in phenotype. This phenomenon occurs during regeneration from callus or if a meristem is damaged (Kulus et al. 2019). Chimeras are often created due to mutation breeding, a method commonly used for chrysanthemum (Su et al. 2019); chimeral plants may also occur regardless of mutagen use (Kulus et al. 2019).

Genetic variation can be detected in young plants using molecular markers, such as Amplified Fragment Length Polymorphism (AFLP), Inter Simple Sequence Repeats (ISSR), Random Amplification of Polymorphic DNA (RAPD) or Start Codon Targeted Polymorphism (SCoT), multi-omics approaches (Butiuc-Keul et al. 2016). These methods, however, are expensive, time-consuming, and require the use of numerous primers to obtain reliable results. On the other hand, chemotaxonomical array analysis based on the pigment content in petals, is cheaper but can only be performed on mature plants at the stage of blooming (LemaRumińska et al. 2018). Flow-cytometric (FCM) determination of nuclear DNA content is a relatively simple, fast, and inexpensive method of verifying genome size stability. It requires only a small amount of biological material and can be performed at the in-vitro-multiplication stage (Ochatt 2008; Ochatt et al. 2013). FCM measurement of 
DNA content has been used to confirm genome size stability of numerous in-vitro-propagated medicinal and horticultural species (Sliwinska 2018). It has been applied also for genome size estimation of several Chrysanthemum species (Leitch et al. 2019; 2C range 5.84-35.90 pg). Nuclear DNA content of $6 x$ Chrysanthemum $\times$ morifolium estimated by Feulgen microdensitometry is 19.2-21.0 pg/2C (Ohri et al. 1981); FCM has not been used to verify this value until the present study. There are no reports on the application of FCM for the detection of variation between periclinal chimeras of micropropagated chrysanthemum. The information on the effect of mutagenic treatment on nuclear DNA content is limited to a single cultivar of $C . \times$ morifolium subjected to $\gamma$-irradiation and ion beams irradiation (Yamaguchi et al. 2008, 2010). These studies revealed that the relative DNA content in the induced mutants was reduced, likely due to DNA damage such as in chromosomal aberrations and/or by reduction of chromosome number. This reduction was total-dose- and dose-rate-dependent.

The current study is aimed to (i) evaluate the genome size and inflorescence colour stability of 11 chrysanthemum cultivars (solid and chimera mutants) propagated in vitro in media with and without PGRs; (ii) determine whether FCM measurement of DNA content during in vitro multiplication can detect somaclonal variation and/or chimera component separation that normally would appear later at flowering (inflorescence colour); (iii) study the influence of irradiation type (X-or $\gamma$-rays) on mutant genome size.

\section{Materials and methods}

\section{Plant material and in vitro culture conditions}

Eleven cultivars of Chrysanthemum $\times$ morifolium (Ramat.) Hemsl., of the Lady cultivar group were used, created through $\mathrm{X}$ - and $\gamma$-radiation (total dose $15 \mathrm{~Gy}$, dose rate 0.92 and 1.92 for $\mathrm{X}$ - and $\gamma$-ray treatment, respectively; Jerzy and Zalewska 1997). Six cultivars, including the mother cultivar 'Richmond', were solid mutants and five were periclinal chimeras (Zalewska et al. 2007; Table 1).

Single-node shoot fragments of each cultivar were vertically inoculated in 350-mL glass jars filled with $40 \mathrm{~mL}$ MS (Murashige and Skoog 1962) medium, either without PGRs (medium A) or supplemented with $0.6 \mathrm{mg} \mathrm{L}^{-1} \mathrm{BA}$ and $2.0 \mathrm{mg} \mathrm{L}^{-1}$ IAA (Sigma-Aldrich, St. Louis, MO, USA; medium B). The media were additionally supplemented with $30 \mathrm{~g} \mathrm{~L}^{-1}$ of sucrose and solidified with $8.0 \mathrm{~g} \mathrm{~L}^{-1}$ agar (Biocorp, Warsaw, Poland). After adding all the components, the $\mathrm{pH}$ was adjusted to 5.8 before the medium was autoclaved at $121{ }^{\circ} \mathrm{C}$ and $105 \mathrm{kPa}$ for $20 \mathrm{~min}$. Ten explants were used for each cultivar in five repetitions for each medium type.
Table 1 In vitro multiplication rates of 11 chrysanthemum $(C . \times$ morifolium $)$ cultivars in different media

\begin{tabular}{lllll}
\hline Cultivar & $\begin{array}{l}\text { Type of irradiation } \\
\text { used for the crea- } \\
\text { tion of cultivar }\end{array}$ & $\begin{array}{l}\text { Number of shoots per } \\
\text { explant }( \pm \text { SE) }\end{array}$ & HSD \\
\cline { 3 - 4 } & & Medium A & Medium B & \\
\hline Richmond & None & $1.0 \pm 0.0 \mathrm{a}$ & $1.4 \pm 0.4 \mathrm{~b}$ & n.s. \\
Lady Amber & $\mathrm{X}$ & $1.0 \pm 0.0 \mathrm{a}$ & $3.0 \pm 0.6 \mathrm{a}$ & 2.0 \\
Lady Apricot* & $\gamma$ & $1.0 \pm 0.0 \mathrm{a}$ & $1.3 \pm 0.3 \mathrm{~b}$ & n.s. \\
Lady Bronze* & $\mathrm{X}$ & $1.0 \pm 0.0 \mathrm{a}$ & $1.2 \pm 0.2 \mathrm{~b}$ & n.s. \\
Lady Orange* & $\mathrm{X}$ & $1.0 \pm 0.0 \mathrm{a}$ & $1.6 \pm 0.2 \mathrm{~b}$ & n.s. \\
The Lady Pink & $\mathrm{X}$ & $1.0 \pm 0.0 \mathrm{a}$ & $1.8 \pm 0.4 \mathrm{ab}$ & 0.8 \\
Lady Rosy* & $\mathrm{X}$ & $1.0 \pm 0.0 \mathrm{a}$ & $1.4 \pm 0.4 \mathrm{~b}$ & n.s. \\
Lady Salmon* & $\mathrm{X}$ & $1.0 \pm 0.0 \mathrm{a}$ & $2.4 \pm 0.5 \mathrm{ab}$ & 1.4 \\
Lady Vitroflora & $\gamma$ & $1.0 \pm 0.0 \mathrm{a}$ & $2.0 \pm 0.3 \mathrm{ab}$ & 1.0 \\
Lady White & $\gamma$ & $1.0 \pm 0.0 \mathrm{a}$ & $2.2 \pm 0.5 \mathrm{ab}$ & 1.2 \\
Lady Yellow & $\gamma$ & $1.0 \pm 0.0 \mathrm{a}$ & $1.4 \pm 0.4 \mathrm{~b}$ & n.s. \\
Mean & & $1.0 \pm 0.0$ & $1.8 \pm 0.4$ & 0.8 \\
\hline
\end{tabular}

Values \pm SE in columns followed by the same letter do not differ significantly at $P=0.05$ (Tukey's test)

$H S D$ honest significant difference in rows, n.s. no significant difference

Cultivars marked with an asterisk (*) are periclinal chimeras; medium A-MS PGR-free; medium B-MS with $0.6 \mathrm{mg} \mathrm{L}^{-1} \mathrm{BA}$ and $2.0 \mathrm{mg}$ $\mathrm{L}^{-1}$ IAA

The cultures were grown at $24 \pm 1{ }^{\circ} \mathrm{C}$ and exposed to a 16-h photoperiod. Standard cool daylight was provided by TLD54/36W fluorescent lamps (Koninklijke Philips Electronics N.V., Eindhoven, the Netherlands) with the photosynthetic photon flux density of approximately $35 \mu \mathrm{mol}$ $\mathrm{m}^{-2} \mathrm{~s}^{-1}$ and colour temperature of $6200 \mathrm{~K}$.

After 8 weeks, all produced shoots were counted, cut (approximately $5 \mathrm{~cm}$ long), and transferred into solid MS rooting medium with $2.0 \mathrm{mg} \mathrm{L}^{-1}$ IAA for another 10 days under the same conditions as previous.

\section{Estimation of DNA content in in vitro-derived plantlets by flow cytometry (FCM)}

The second and third leaves of each 8-week-old shoot were sampled to measure DNA content. Samples for FCM were prepared according to Rewers et al. (2012), using nucleiisolation buffer $\left(0.1 \mathrm{M}\right.$ Tris; $2.5 \mathrm{mM} \mathrm{MgCl} \cdot 6 \mathrm{H}_{2} \mathrm{O} ; 85 \mathrm{mM}$ $\mathrm{NaCl} ; 0.1 \%$ v/v Triton X-100; pH 7.0) supplemented with propidium iodide (PI; $50 \mu \mathrm{g} \mathrm{mL}^{-1}$ ) and ribonuclease $\mathrm{A}$ $\left(50 \mu \mathrm{g} \mathrm{mL}^{-1}\right)$. Pisum sativum 'Set' $(2 \mathrm{C}=9.11 \mathrm{pg}$; Sliwinska et al. 2005) served as an internal standard. For each sample, at least 7000 nuclei were analyzed using a CyFlow SL Green (Partec GmbH, Münster, Germany) flow cytometer, equipped with a high-grade solid-state laser with green light emission at $532 \mathrm{~nm}$, long-pass filter RG 590 E, DM 560 A, as well as with side (SSC) and forward (FSC) scatters. 
Analyses were performed on 5-15 biological replicates, depending on plantlet availability, using linear amplification. Histograms were evaluated using FloMax software (Partec $\mathrm{GmbH}$, Münster, Germany). The coefficient of variation (CV) of the $\mathrm{G}_{0} / \mathrm{G}_{1}$ peak of chrysanthemum species ranged between 2.70 and $5.33 \%$. Nuclear DNA content was calculated using the linear relationship between the ratio of the $2 \mathrm{C}$ peak positions of chrysanthemum/internal standard on a histogram of fluorescence intensities. The $2 \mathrm{C}$ nuclear DNA content in picograms (pg) was transformed into megabase pairs (Mbp) of nucleotides, using the conversion $1 \mathrm{pg}=978$ Mbp (Doležel et al. 2003).

\section{Acclimatization and evaluation of plant colour}

Acclimatization was performed for 10 days in April in a glasshouse at $18-21{ }^{\circ} \mathrm{C}$. Plants were grown in plastic trays filled with a mixture of peat and perlite $(2: 1$; disinfected with $0.2 \%$ v/w Dithane M-45; Dow AgroSciences, Warsaw, Poland), sprayed with water and covered with transparent perforated film and geo-cover. Then, the plants were transferred to plastic pots filled with commercial peat substrate for chrysanthemum cultivation (Gramoflor Cultivo, Vechta, Germany) and placed on glasshouse benches. The plants were cultivated in natural photoperiod and brought to flowering as one stem with a single inflorescence. The colour of the inside and outside ligulate flowers of fully-developed inflorescences was established visually using the Royal Horticultural Society Colour Chart (RHSCC 1966).

\section{Statistical analysis}

The results were evaluated by the two-factor analysis of variance (ANOVA) and the HSD Tukey's test at $P=0.05$ using Statistica 12.0 (Statsoft, Cracow, Poland) and Excel add-in ANALWAR-5.2-FR tools.

\section{Results and discussion}

\section{In vitro shoot development and genome size variation of radiomutants}

Cytokinins and auxins are routinely applied during micropropagation of plants to increase propagation rate and to improve the production efficiency (Kereša et al. 2012; Kulus 2020). Unfortunately, callus formation and indirect regeneration of adventitious shoots in the presence of PGRs, especially cytokinins, may cause some perturbation in the stability of the resultant plants (Krishna et al. 2016; Vitamvas et al. 2019). To examine if PGRs influence nuclear DNA content of in vitro produced plants, two types of media were used, medium A (PGR-free) and medium B (supplemented with BA and IAA).

Only single shoots developed from nodal segments cultured in medium A, in all 11 cultivars (Table 1). Nodal segments grown in medium B produced more shoots per explant (1-3; mean 1.8). In medium A shoots were produced via direct organogenesis from lateral buds, but callus was formed at the base of explants cultured in medium B, from which adventitious shoots regenerated (Supplementary Fig. 1). Chrysanthemum 'Lady Amber' produced the highest number of shoots (mean 3.0) per explant (Table 1). The effect of genotype on the multiplication rate was in agreement with earlier findings by Kulus and Zalewska (2014), who detected differences in sprouting efficiency among four chrysanthemum cultivars from the Lady group cultured in the PGR-free MS medium. The addition of PGRs into the culture medium resulted in an increased multiplication rate in five of 11 cultivars tested (Table 1). All shoots were vigorous and able to spontaneously regenerate adventitious roots, regardless of the cultivar or medium composition. The type of mutagen used by Jerzy and Zalewska (1997) for
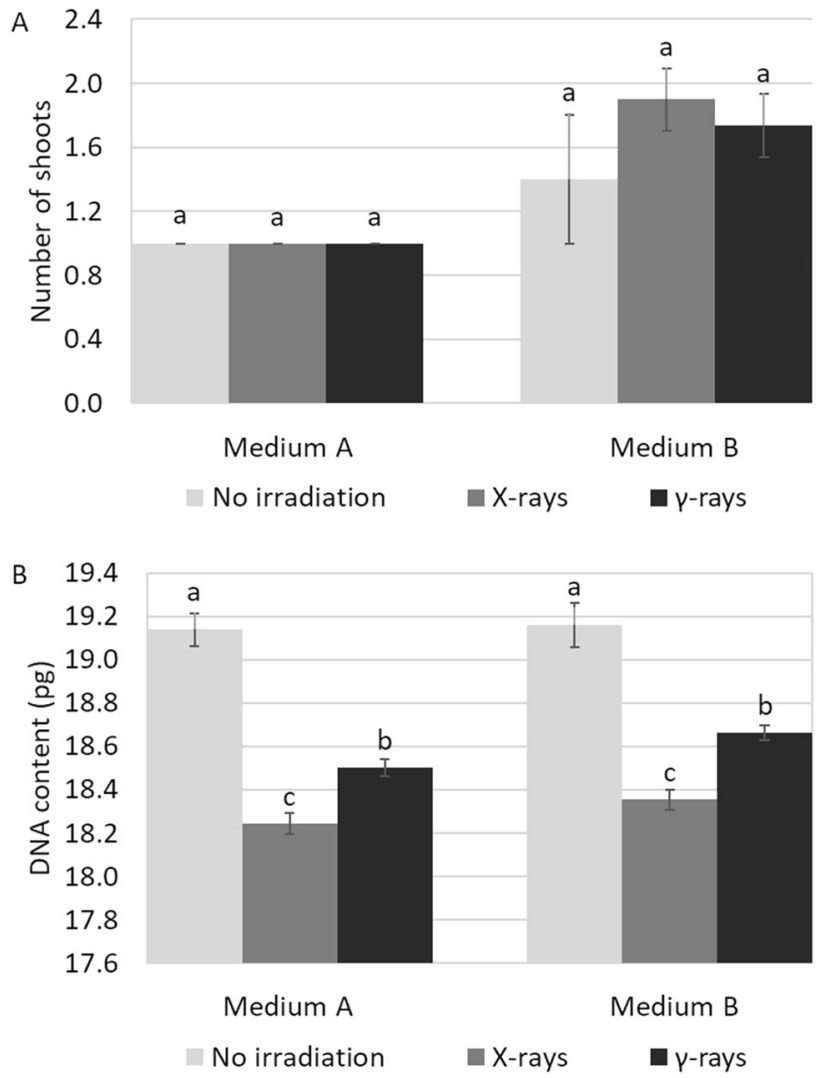

Fig. 1 Effect of mutation origin (irradiation type) of the Lady group chrysanthemum radiomutants on the multiplication rate (A) and nuclear DNA content (B) compared to the mother non-irradiated cultivar 'Richmond' 
the creation of the cultivars did not affect the proliferation ratio during the single tested multiplication cycle (Fig. 1a).

The ploidy of Chrysanthemum spp. varies from diploid to octoploid and the number of chromosomes can reach 72 ( $8 x$ cultivar of $C . \times$ morifolium; Leitch et al. 2019). Most contemporary ornamental $C . \times$ morifolium cultivars are hexaploids, but due to centuries of both intra- and interspecific crosses, and, more recently, mutation breeding, many cultivars are aneuploids $(2 n=6 x=54 \pm 7 \sim 10$ chromosomes; Teixeira da Silva et al. 2013). As established previously, chrysanthemums cultivars belonging to the Lady group used here are hexaploids and possess 54 chromosomes (Lema-Rumińska and Zalewska 2002). Genome size of the hexaploid species studied so far varies between 16.13 and $19.90 \mathrm{pg} / 2 \mathrm{C}$ (Leitch et al. 2019) and the genome size of $C . \times$ morifolium (17.95-19.16 pg/2C; Table 2) studied here falls within this range. Our estimation of the genome size of $C . \times$ morifolium is similar to this established for hexaploid cultivars by Ohri et al. (1981) using Feulgen microdensitometry.

Within an intact periclinal chimera, the differences in DNA content between individual component genotypes are impossible to establish cytometrically due to difficulties in separation of different cell layers. It is only possible after their separation during regeneration in vitro. The addition of PGRs to the culture medium affected the nuclear DNA content in two out of 11 cultivars; genomes of 'Lady Apricot' and 'Lady Salmon' (both chimeric cultivars) plants derived from medium B were larger (18.63 and $18.75 \mathrm{pg} / 2 \mathrm{C}$, respectively) than for plants grown in medium A (18.32 and $18.51 \mathrm{pg} / 2 \mathrm{C}$, respectively; Table 2, Fig. 2). This increase, however, was only $1.7 \%$ in 'Lady Apricot' and $1.3 \%$ in 'Lady Salmon', which is attributable to a variation in the level of individual chromosomes and not the whole genome (i.e. polyploidization). Similarly, no ploidy changes were detected in chrysanthemums produced via somatic embryogenesis, which grew either in MS PGR-free or supplemented with PGRs media (Lema-Rumińska and Sliwinska 2009, 2015; Naing et al. 2013). However, in those reports only relative DNA content/DNA ploidy was established, which did not allow the detection of smaller than genomic changes.

The present study revealed that all ten radiomutants of the Lady group possessed a lower nuclear DNA content (17.95-18.75 pg/2C) than the mother cultivar 'Richmond' (about $19.15 \mathrm{pg} / 2 \mathrm{C}$ ), regardless of the culture medium used for multiplication (Table 2). This suggests that the applied mutagens (X-and $\gamma$-irradiation) caused considerable deletions from the genome of the original 'Richmond' cultivar. This also may be a result of the stress from irradiation, which negatively affects the synthesis of DNA, as reported in other plant species (Oladosu et al. 2016). The decrease in DNA content caused by mutations observed here, which varied with the cultivar, was substantial and varied from about $1.6 \%$ to almost $6 \%$. A similar negative effect of irradiation (gamma and ion beam) on DNA content in C. morifolium was reported previously by Yamaguchi et al. $(2008,2010)$. Their studies revealed also a negative correlation between the dose of gamma/ion beam irradiation applied to explants and the relative DNA content in regenerants. However, no genome sizes of the mutants were established, so the actual amount of the DNA decrease is unknown.
Table 2 Nuclear DNA content of 11 chrysanthemum (C. $\times$ morifolium $)$ cultivars growing in vitro in different media

\begin{tabular}{|c|c|c|c|c|c|}
\hline \multirow[t]{3}{*}{ Cultivar } & \multicolumn{4}{|l|}{ 2C DNA content } & \multirow[t]{3}{*}{ HSD [pg] } \\
\hline & \multicolumn{2}{|l|}{ Medium A } & \multicolumn{2}{|l|}{ Medium B } & \\
\hline & $p g( \pm S E)$ & Mbp & $\mathrm{pg}( \pm \mathrm{SE})$ & Mbp & \\
\hline Richmond & $19.14 \pm 0.08 \mathrm{a}$ & 18,719 & $19.16 \pm 0.10 \mathrm{a}$ & 18,738 & n.s. \\
\hline Lady Amber & $18.08 \pm 0.04$ ef & 17,682 & $18.10 \pm 0.02 \mathrm{~d}$ & 17,702 & n.s. \\
\hline Lady Apricot* & $18.32 \pm 0.05 \mathrm{cde}$ & 17,917 & $18.63 \pm 0.04 \mathrm{bc}$ & 18,220 & 0.31 \\
\hline Lady Bronze* & $18.62 \pm 0.06 \mathrm{~b}$ & 18,210 & $18.75 \pm 0.10 b$ & 18,338 & n.s. \\
\hline Lady Orange* & $18.08 \pm 0.03$ ef & 17,682 & $18.14 \pm 0.04 \mathrm{~d}$ & 17,741 & n.s. \\
\hline Lady Pink & $18.21 \pm 0.06 \mathrm{de}$ & 17,809 & $18.37 \pm 0.03 \mathrm{~cd}$ & 17,966 & n.s. \\
\hline Lady Rosy* & $17.95 \pm 0.06 \mathrm{f}$ & 17,555 & $18.03 \pm 0.04 \mathrm{~d}$ & 17,633 & n.s. \\
\hline Lady Salmon* & $18.51 \pm 0.08 \mathrm{bc}$ & 18,103 & $18.75 \pm 0.08 \mathrm{~b}$ & 18,338 & 0.25 \\
\hline Lady Vitroflora & $18.54 \pm 0.06 \mathrm{bc}$ & 18,132 & $18.73 \pm 0.10 \mathrm{~b}$ & 18,318 & n.s. \\
\hline Lady White & $18.48 \pm 0.06 \mathrm{bcd}$ & 18,073 & $18.60 \pm 0.04 \mathrm{bc}$ & 18,191 & n.s. \\
\hline Lady Yellow & $18.67 \pm 0.05 b$ & 18,259 & $18.69 \pm 0.04 \mathrm{bc}$ & 18,279 & n.s. \\
\hline Mean & $18.42 \pm 0.04$ & 18,015 & $18.54 \pm 0.06$ & 18,133 & 0.12 \\
\hline
\end{tabular}

Values \pm SE in columns followed by the same letter do not differ significantly at $P=0.05$ (Tukey's test) $H S D$ honest significant difference in rows, $n$.s. no significant difference

Cultivars marked with an asterisk (*) are periclinal chimeras; medium A-MS PGR-free; medium B-MS with $0.6 \mathrm{mg} \mathrm{L}^{-1} \mathrm{BA}$ and $2.0 \mathrm{mg} \mathrm{L}^{-1} \mathrm{IAA}$ 
Fig. 2 Example histograms of fluorescence intensity of propidium iodide (PI) in the nuclei of Pisum sativum 'Set' and Chrysanthemum $\times$ morifolium: $1-2 \mathrm{C}$ pea peak, $2-2 \mathrm{C}$ chrysanthemum peak medium A

medium B

Lady Apricot
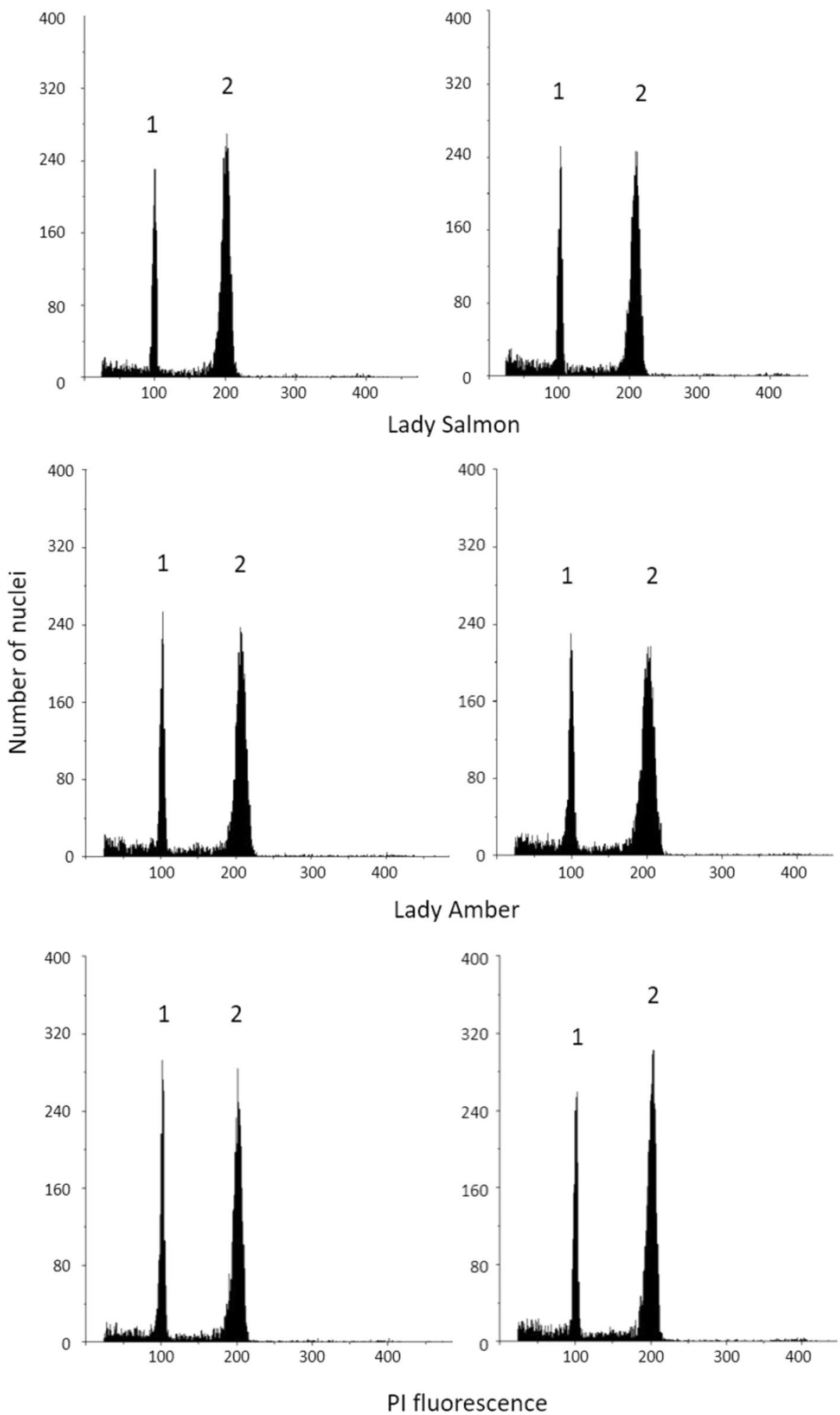
FCM analyses of the in vitro shoots of cultivars belonging to the Lady group revealed differences between their genome sizes (Table 2). Within the cultivars grown in medium A the lowest DNA content, below $18 \mathrm{pg} / 2 \mathrm{C}$, was in 'Lady Rosy', and the highest in 'Lady Bronze' (18.62 pg/2C) and 'Lady Yellow' (18.67 pg/2C). DNA contents in plants grown in medium $\mathrm{B}$ were less diversified, with the lowest DNA content, slightly above $18 \mathrm{pg} / 2 \mathrm{C}$, in 'Lady Amber', 'Lady Orange' and 'Lady Rosy', while the remaining cultivars possessed 18.4-18.7 pg/2C. Interestingly, the mean genome size of the cultivars obtained by X-ray irradiation was significantly lower than that of the cultivars obtained by $\gamma$-irradiation (Fig. 1b). This suggests a greater DNA damage caused by $\mathrm{X}$-rays while inducing mutations in chrysanthemum.

\section{Ex vitro growth and inflorescence colour of plants}

Chrysanthemum rooting and acclimatization were fully successful (100\% survival rate), regardless of the medium composition, mutant type, and cultivar. The microshoots developed evenly into healthy plants; no phenotype alteration occurred during the vegetative growth.

The use of meristematic explants is necessary during the in vitro propagation of a periclinal chimera to maintain the arrangement of its histogen layers (Zalewska et al. 2007). In the current study, all shoots growing from nodal segments in the PGR-free medium A produced inflorescences of the same colour as the donor plants. However, there were changes in inflorescence colour in all or part of the plants of 'Lady Amber', 'Lady Apricot', and 'Lady Salmon' cultivars grown in medium B, supplemented with PGRs (Table 3; Supplementary Fig. 2). Those changes could be due to somaclonal variation or separation of the components of periclinal chimeras, or both.

Among 15 plants of 'Lady Amber' that regenerated in medium B, 13 reproduced the original yellow inflorescence, but two were amber (Table 3). This cultivar is a solid mutant (Zalewska et al. 2007) and no differences in DNA content between plants cultured in medium A and B were detected by FCM (Table 2). Thus, inflorescence colour change could have been the result of point mutation(s) undetectable by this method. For those plants, the detection of genetic stability using molecular markers or genome sequencing need to be applied (Miler and Zalewska 2014; Butiuc-Keul et al. 2016; Jo and Kim 2019).

A separation of chimera components probably occurred in 'Lady Apricot' and 'Lady Salmon' chrysanthemums produced in medium B. All 'Lady Apricot' plants produced purple inflorescences instead of orange and those of 'Lady Salmon' segregated into pale flesh pink and creamy pink $(5,2$, and 4 plants, respectively). The hypothesis of separation of chimera components is supported by the results of Zalewska et al. (2007), who by using the same cultivars obtained a separation among plants produced from leaf explants; plants of 'Lady Apricot' produced purple and purple-gold inflorescences, and of 'Lady Salmon' pink and white. Chimera compounds separation was also reported by Canli and Skirvin (2008) for Rosa multiflora Thunb ex. J. Murr. cultured in vitro under various levels of BA. In their study, the chimeral thornless sport 'Fairmount 1' separated into its constituent genotypes and yielded thorny and thornless plantlets. Since the authors found a linear positive relationship between BA concentration and the percentage of thorny plants, they suggested that BA stimulates chimeral segregation. In the present experiment, it was expected that in 'Lady Apricot' chrysanthemums at least some of the plants would exhibit the typical orange fluorescence phenotype of the cultivar, but all plants produced purple inflorescences in medium B. This indicates the high instability of this cultivar, in which the rearrangement of histogen layers in the axillary meristem probably took place in the presence of PGRs.

Changes in the phenotype of 'Lady Apricot' and 'Lady Salmon' chrysanthemums produced in medium B coincide with an increase in nuclear DNA content (Table 2). This is indicative of considerable differences in DNA content between particular histogen layers in these cultivars. This is supported by studies on DNA polymorphism using RAPD markers in three chrysanthemum cultivars and their radiomutants, which revealed differences between two genotypes co-existing within one chimera plant (Miler and Zalewska 2014). Cytochimerism was not detected (i.e. plants of different ploidies) in the studied material. In contrast, lemon plants recovered from $\gamma$-irradiated embryonic callus contained diploid and tetraploid cells (Obrović et al. 2008).

The genome size and inflorescence colour of 'Lady Bronze', 'Lady Orange', and 'Lady Rosy' chrysanthemums, which are periclinal chimeras, remain stable after multiplication in PGR-fortified medium (Table 3).

\section{Conclusions}

Genome size estimation is one method to check the genetic stability of plant material produced in vitro (Sliwinska 2018). The present research reveals that in chimeric chrysanthemum cultivars an increase of DNA content in plants grown in PGRsupplemented medium coincides with a change in inflorescence colour in the mature plants (Supplementary Table 1). Lack of increased DNA content indicates stability of inflorescence colour. Among solid mutants, which are considered to be genetically stable, in one of five cultivars inflorescence colour changed without a change in DNA content. In the changed cultivar, somaclonal variation was below FCM detectability. 
Table 3 Inflorescence colours of regenerants of 11 chrysanthemum $(C . \times$ morifolium $)$ cultivars grown in different media.

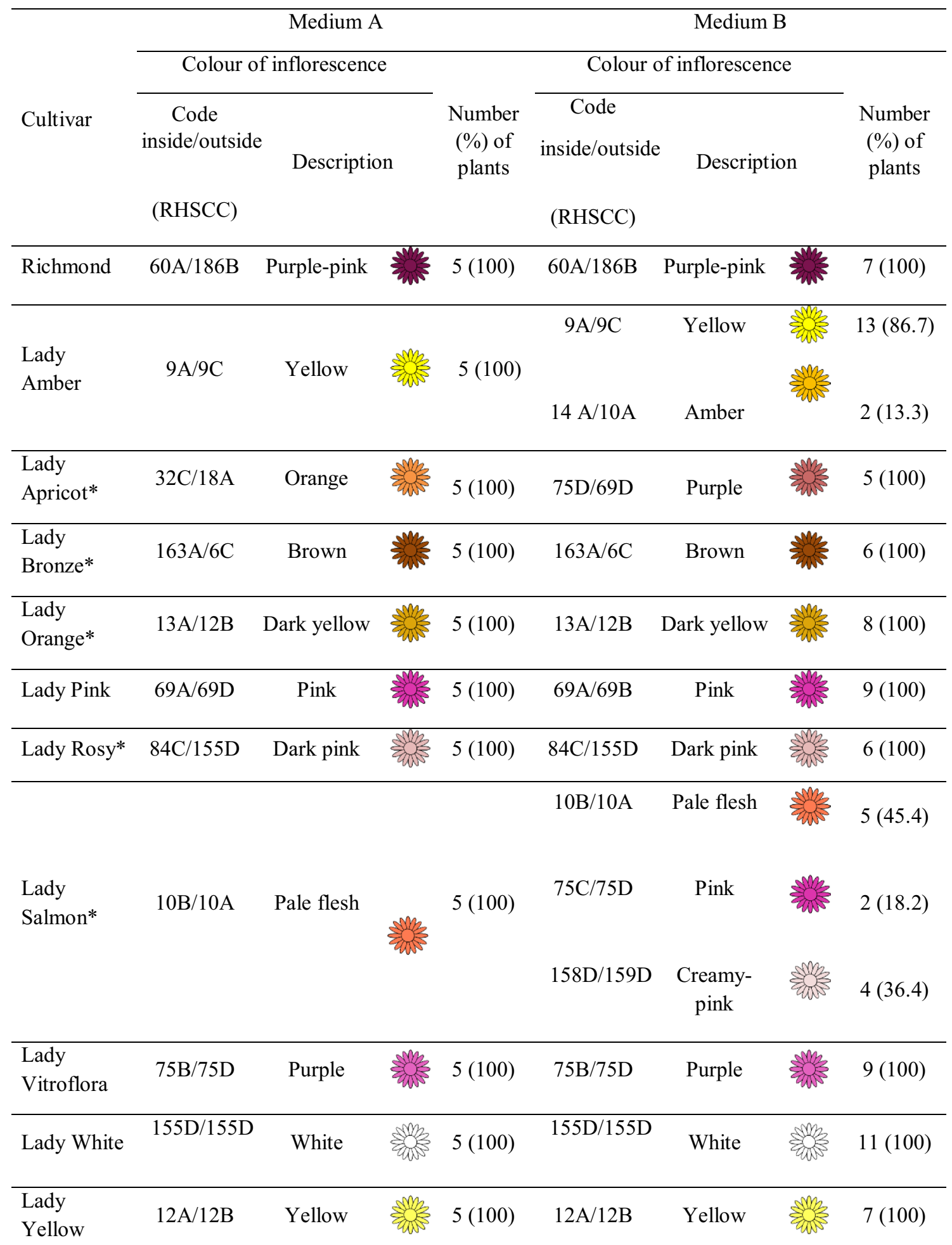

Cultivars marked with an asterisk $\left(^{*}\right)$ are periclinal chimeras; medium A-MS PGR-free; medium B-MS with $0.6 \mathrm{mg} \mathrm{L}^{-1} \mathrm{BA}$ and $2.0 \mathrm{mg} \mathrm{L}{ }^{-1}$ IAA

RHSCC Royal Horticultural Society Colour Chart (1966) 
In the unchanged four, PGRs addition did not cause a change in either DNA content or inflorescence colour. Thus, genome size estimates at the early stage of plant production in 10 out of 11 cultivars correctly indicates either stability or change of the inflorescence colour (only in 'Lady Amber' inflorescence colour changed despite a stable genome size). Consequently, FCM measurement of nuclear DNA content at the in vitro multiplication stage can be recommended for detection of variation in this important phenotypic trait in chrysanthemums especially in periclinal chimeras. FCM does not guarantee detection of small changes in DNA content (below $1 \%$ ) in solid mutants; for such material molecular methods are required to estimate genetic stability.

The addition of PGRs to culture media improves the multiplication efficiency in some chrysanthemum cultivars, although it may affect the genetic stability, even when using nodal segments as the source of explants. Due to the high risk of uniformity loss, which in three cultivars in the current study varied from 13 to $100 \%$ of plants with changed inflorescence colour, micropropagation of chrysanthemum should be performed using meristematic explants and in a medium without PGRs. This protocol, despite a lower multiplication rate, guarantees the maintenance of genetic integrity in the cultivar, which, in turn, eliminates the risk of financial losses due to the production of uneven plant material. However, if producers prefer to increase the multiplication rate, the risk of losing genetic fidelity of the commercial plant material can be considerably lowered by using FCM analysis or eliminated by use of molecular markers.

As shown here, FCM can be also applied in chrysanthemum mutation breeding for radiomutant screening. Since irradiation causes DNA damage, mutants possess a lowered nuclear content compared to the original plant material, especially after using X-rays.

Acknowledgements The authors wish to thank Professor J. Derek Bewley, University of Guelph, Canada for critical comments to the manuscript, and Joanna Wojciechowska, UTP University of Science and Technology in Bydgoszcz, Poland for technical support in performing this research.

Author contributions NM conceived and designed research, NM and ES conducted the experiments, NM, DK, and ES analyzed the data and wrote the manuscript.

Funding Not applicable.

Data availability Data available by e-mail on reasonable request.

\section{Compliance with ethical standards}

Conflict of interest The authors declare that they have no conflict of interest.
Open Access This article is licensed under a Creative Commons Attribution 4.0 International License, which permits use, sharing, adaptation, distribution and reproduction in any medium or format, as long as you give appropriate credit to the original author(s) and the source, provide a link to the Creative Commons licence, and indicate if changes were made. The images or other third party material in this article are included in the article's Creative Commons licence, unless indicated otherwise in a credit line to the material. If material is not included in the article's Creative Commons licence and your intended use is not permitted by statutory regulation or exceeds the permitted use, you will need to obtain permission directly from the copyright holder. To view a copy of this licence, visit http://creativecommons.org/licenses/by/4.0/.

\section{References}

Butiuc-Keul A, Farkas A, Cristea V (2016) Genetic stability assessment of in vitro plants by molecular markers. Stud Univ BabesBolyai Biol 1:107-114

Canli FA, Skirvin RM (2008) In vitro separation of a rose chimera. Plant Cell Tissue Organ Cult 95:353-361. https://doi. org/10.1007/s11240-008-9449-y

Doležel J, Bartoš J, Voglmayr H, Greilhuber J (2003) Nuclear DNA content and genome size of trout and human. Cytometry 51A:127-128. https://doi.org/10.1002/cyto.a.10013

Jerzy M, Zalewska M (1997) Flower colour recurrence in chrysanthemum and gerbera mutants propagated in vitro with meristems and leaf explants. Acta Hortic 417:611-614. https://doi. org/10.17660/ActaHortic.1997.447.121

Jo YD, Kim J-B (2019) Frequency and spectrum of radiation-induced mutations revealed by whole genome sequencing. Quant Beam Sci 3(2):7. https://doi.org/10.3390/qubs3020007

Kereša S, Mihovilović A, Barić M, Židovec V, Skelin M (2012) The micropropagation of chrysanthemums via axillary shoot proliferation and highly efficient plant regeneration by somatic embryogenesis. Afr J Biotechnol 11:6027-6033. https://doi.org/10.5897/ AJB10.1976

Krishna H, Alizadeh M, Singh D, Singh U, Chauhan N, Eftekhari M, Sadh RK (2016) Somaclonal variations and their applications in horticultural crops improvement. 3 Biotech 6(1):54. https://doi. org/10.1007/s13205-016-0389-7

Kulus D (2015) Selected aspects of ornamental plants micropropagation in Poland and worldwide. Life Sci 4:10-25. https://doi. org/10.13140/RG.2.1.5086.8082

Kulus D (2020) Influence of growth regulators on the development, quality, and physiological state of invitro-propagated Lamprocapnos spectabilis (L.) Fukuhara. In Vitro Cell Dev Biol Plant 56(4):447-457. https://doi.org/10.1007/s11627-020-10064-1

Kulus D, Zalewska M (2014) In vitro plant recovery from alginate encapsulated Chrysanthemum $\times$ grandiflorum /Ramat./Kitam. shoot tips. Prop Ornam Plants 14:3-12

Kulus D, Abratowska A, Mikuła A (2018) Morphogenetic response of shoot tips to cryopreservation by encapsulation-dehydration in a solid mutant and periclinal chimeras of Chrysanthemum $\times$ grandiflorum/Ramat./Kitam. Acta Physiol Plant 40:18. https://doi. org/10.1007/s11738-017-2593-4

Kulus D, Rewers M, Serocka M, Mikuła A (2019) Cryopreservation by encapsulation-dehydration affects the vegetative growth of chrysanthemum but does not disturb its chimeric structure. Plant Cell Tissue Organ Cult 138:153-166. https://doi.org/10.1007/s1124 0-019-01614-6

Larkin PJ, Scowcroft WR (1981) Somaclonal variation a novel source of variability from cell cultures for plant improvement. Theoret Appl Genet 60:197-214. https://doi.org/10.1007/BF02342540 
Leitch IJ, Johnston E, Pellicer J, Hidalgo O, Bennett MD (2019) Plant DNA C-values database (release 7.1, Apr 2019). https://cvalu es.science.kew.org/

Lema-Rumińska J, Zalewska M (2002) Evaluation of ploidy in chrysanthemum mutants (Dendranthema grandiflora Tzvelev) obtained in mutagenesis induced in vitro and in vivo by ionizing radiation. Acta Sci Pol Hort Cult 1:43-48

Lema-Rumińska J, Sliwinska E (2009) Evaluation the stability of plants obtained from the somatic embryos in chrysanthemum (Chrysanthemum $\times$ grandiflorum/Ramat./Kitam.). Zesz Probl Post Nauk Rol 539:425-432

Lema-Rumińska J, Sliwinska E (2015) Evaluation of the genetic stability of plants obtained via somatic embryogenesis in Chrysanthemum $\times$ grandiflorum (Ramat./Kitam.). Acta Sci Pol Hort Cult 14:131-139

Lema-Rumińska J, Miler N, Gęsiński K (2018) Identification of new polish lines of Chenopodium quinoa (Willd.) by spectral analysis of pigments and a confirmation of genetic stability with SCoT and RAPD markers. Acta Sci Pol Hort Cult 17:75-86. https://doi. org/10.24326/asphc.2018.1.7

Miler N, Zalewska M (2014) Somaclonal variation of chrysanthemum propagated in vitro from different explant types. Acta Sci Pol Hort Cult 13:69-82. https://doi.org/10.24326/asphc.2018.1.7

Miler N, Jędrzejczyk I (2018) Chrysanthemum plants regenerated from ovaries: a study on genetic and phenotypic variation. Turk J Bot 42:289-297. https://doi.org/10.3906/bot-1707-19

Murashige T, Skoog F (1962) A revised medium for rapid growth and bio assays with tobacco tissue cultures. Physiol Plant 15:473-497. https://doi.org/10.1111/j.1399-3054.1962.tb08052.x

Naing AH, Min JS, Park KI, Chung MY, Lim SH, Lim KB, Kim CK (2013) Primary and secondary somatic embryogenesis in chrysanthemum (Chrysanthemum morifolium) cv. 'Baeksun' and assessment of ploidy stability of somatic embryogenesis process by flow cytometry. Acta Physiol Plant 35:2965-2974

Neelakandan AK, Wang K (2012) Recent progress in the understanding of tissue culture-induced genome level changes in plants and potential applications. Plant Cell Rep 31:597-620. https://doi. org/10.1007/s00299-011-1202-z

Ochatt SJ (2008) Flow cytometry in plant breeding. Cytometry 73A:581-598. https://doi.org/10.1002/cyto.a.20562

Ochatt SJ, Conreux C, Jacas L (2013) Flow cytometry distinction between species and between landraces within Lathyrus species and assessment of true-to-typeness of in vitro regenerants. Plant Syst Evol 299:75-85. https://doi.org/10.1002/cyto.a.20562

Ohri D, Nazeer MA, Pal M (1981) Cytophotometric estimation of nuclear DNA in some ornametals. Nucleus 24:39-42

Oladosu Y, Rafii MY, Abdullah N, Hussin G, Ramli A, Rahim HA, Miah G, Usman MG (2016) Principle and application of plant mutagenesis in crop improvement: a review. Biotechnol Biotechnol Equip 30:1-16. https://doi.org/10.1080/13102818.2015.10873 33

Orbović V, Ćalović M, Viloria Z, Nielsen B, Gmitter FG Jr, Castle WS, Grosseret JW (2008) Analysis of genetic variability in various tissue culture-derived lemon plant populations using RAPD and flow cytometry. Euphytica 161:329-335. https://doi.org/10.1007/ s10681-007-9559-3

Rewers M, Drouin J, Kisiala A, Sliwinska E, Cholewa E (2012) In vitro regenerated wetland sedge Eriophorum vaginatum L. is genetically stable. Acta Physiol Plant 34:2197-2206. https://doi. org/10.1007/s11738-012-1020-0

RHSCC (1966) The Royal Horticultural Society Colour Chart. London

Sliwinska E (2018) Flow cytometry-a modern method for exploring genome size and nuclear DNA synthesis in horticultural and medicinal plant species. Folia Hortic 30:103-128

Sliwinska E, Zielińska E, Jędrzejczyk I (2005) Are seeds suitable for flow cytometric estimation of plant genome? Cytometry 64A:7279. https://doi.org/10.1002/cyto.a.20122

Su J, Jiang J, Zhang F, Liu Y, Ding L, Chen S, Chen F (2019) Current achievements and future prospects in the genetic breeding of chrysanthemum: a review. Hortic Res 6:109. https://doi.org/10.1038/ s41438-019-0193-8

Teixeira da Silva JA, Kulus D (2014) Chrysanthemum biotechnology: discoveries from the recent literature. Folia Hortic 26:67-77. https ://doi.org/10.2478/fhort-2014-0007

Teixeira da Silva JA, Shinoyama H, Aida R, Matsushita Y, Raj SK, Chen F (2013) Chrysanthemum biotechnology: Quo vadis? Crit Rev Plant Sci 32:21-52. https://doi.org/10.1080/07352 689.2012.696461

Teixeira da Silva JA, Lema-Rumińska J, Tymoszuk A, Kulpa D (2015) Regeneration from chrysanthemum flowers: a review. Acta Physiol Plant 37:36. https://doi.org/10.1007/s11738-015-1773-3

Vitamvas J, Viehmannova I, Cepkova PH, Mrhalova H, Eliasova K (2019) Assessment of somaclonal variation in indirect morphogenesis-derived plants of Arracacia xanthorrhiza. Pesq Agropec Bras 54:e00301. https://doi.org/10.1590/s1678-3921.pab20 19.v54.00301

Yamaguchi H, Shimizu A, Degi K, Morishita T (2008) Effects of dose and dose rate of gamma irradiation on mutation induction and nuclear DNA content in chrysanthemum. Breed Sci 58:331-335

Yamaguchi H, Shimizu A, Hase Y, Tanaka A, Shikazono N, Degi K, Morishita T (2010) Effects of ion beam irradiation on mutation induction and nuclear DNA content in chrysanthemum. Breed Sci 60:398-404. https://doi.org/10.1270/jsbbs.60.398

Zalewska M, Lema-Rumińska J, Miler N (2007) In vitro propagation using adventitious buds technique as a source of new variability chrysanthemum. Sci Hortic 113:70-73. https://doi.org/10.1016/j. scienta.2007.01.019

Publisher's Note Springer Nature remains neutral with regard to jurisdictional claims in published maps and institutional affiliations. 